\title{
PERFORMANCE EVALUATION OF PORTABLE MACHINE FOR TURF GRASS SHEAR
}

\author{
*R. A. A. Ahmed
}

\section{ABSTRACT}

The main objective of this study is to evaluation and develop the cutter blade of the portable machine for turf grass shear to increase its shearing efficiency, used in garden and club selfsame small areas and estimate the operation cost. The performance of portable machine for turf grass shear in terms of field efficiency, cutting efficiency, energy requirements and shearing cost were investigated dependent on change in kinematics parameter (ratio of knife peripheral velocity to machine forward speed), knife types (fixed imported cutting blades and free modified free cutting blades ) with three and four cutter blade during the shearing operation. The operating shear a kinematic parameter of 290 which corresponded to forward speed of $0.25 \mathrm{~m} / \mathrm{s}$, knife velocity of 72 $\mathrm{m} / \mathrm{s}$ was the optimum. The best adjusting of the knife of the machine at cutting height of $4 \mathrm{~cm}$ with moisture content $40 \%$ was used free modified knife with three cutter blade.

\section{INTRODUCTION}

Turf grass in golf courses, clubs, public garden and stadiums play a vital role in population life. Turf grass refines the atmosphere

from the bad particles which cause pollution in the air. The green bed refines the atmosphere from the bad particles of pollution in the air. Green bed is used widely as a playground for most games in different clubs. This process is still operated depending on primitive methods using manual tools or imported machines of highly cost. So, turf grass cutting by means of up to date technology taking into consideration Morad 1995) .Machine performance, field efficiency, fuel requirements and operating cost is an important. Many researches were carried out on the rotary mechanisms of cutting machines and the design variables which affect the cutting efficiency. Prasad and Cupta (1973) found that the cross section area and moisture content of the cut material had significant influence over shearing energy and maximum shearing force.

*Assoc. Prof., of Agri. mach. and power Eng. Dept., Fac. of Agri. Rng.,, Al-Azhar Univ. 
Mored (1981) found that the required force for cutting any material may be divided into two parts. The first part is the inertia force required to move the cutting mechanism, and the second is the shearing force required to shear the material. Inertia force is affected by the square of knife velocity resulting in a sharp increase of cutting energy. The force was found to be affected by knife velocity, machine forward speed, and material moisture content. Awady et al. (1988) reported that rotary disk with cutter blades gave better operation efficiencies (0.45-0.91). Appropriate tip speeds are determined according to forward speed, blade protrusion and other relevant factors. Habib (2002) Found that the cuttings force of the plant materials is the main parametric force affecting knife velocity. Whereas, the tension and bending forces that resulted in the plant stalk are of little effect on the cutting knife velocity. El-Sahar (1988) Indicated that the cuttings force is greatly affected by the diameter of the plant stem. For three types of plant stem of cotton, wheat and lawn, $625 \mathrm{~N}$ force was needed to cut of $9 \mathrm{~mm}$ cotton stalk diameter at $6.5 \%$, for $2.5 \mathrm{~mm}$ diameter lawn stems in bundles of four stems. Decreasing cutting forces at higher moisture contents were due to visibility of the stalk tissues of plant stems. Imbabi (1992) found that the energy requirements for cutting the sesame plants ranged from $4.32-27.03$ Joule / stem according to the moisture content of stems, while the cutting force ranged from $432.14-1351.31 \mathrm{~N} / \mathrm{stem}$ according to the moisture content of stems. Kepner et al., (1982 )mentioned that peripheral speeds generally ranged from 51 to $76 \mathrm{~m} / \mathrm{s}$, but they were somewhat lower than for rotary cutters, they usually range from 46 to $56 \mathrm{~m} / \mathrm{s}$ or less.

The objectives of the present research is:

1. Performance evaluation of portable machine used in turf grass shear to improve its performance and minimize the operation cost.

2. Selecting the optimum conditions (kinematic parameter) and the optimum cutting blade for operating the machine.

\section{MATERIALS AND METHODS}

In this study, the portable machine turf grass shear of CG520, Chine made ( shoulder brush type) was used for with imported and modified blades under study. The blade modification process was manufacture at 
some private workshop in Kafrelsheikh City, Egypt. The experiments were carried out in Kafrelsheikh City small garden during the year of 2017. .

\section{A - Materials:}

\section{1 - Turf grass variety.}

Experiments were carried out on Turf grass variety Paspalum this grass spread it"s cultivation in Egypt. The moisture content of Turf grass at the time of experiment was $40 \%$ w.b.

\section{2 - portable machine}

- The portable machine installation used in this study as shown fig (1).

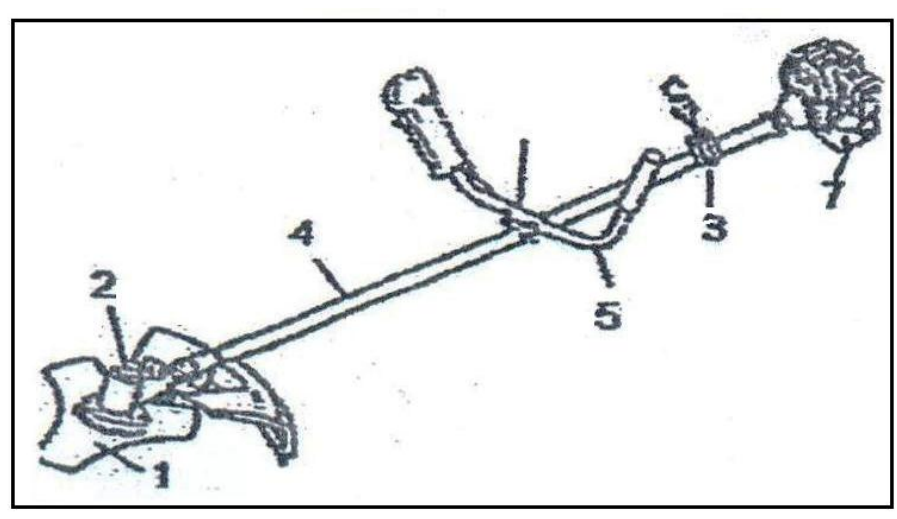

\begin{tabular}{|l|l|}
\hline 1. & Cutting blade. \\
\hline 2. & Rotor head. \\
\hline 3. & Cover protection. \\
\hline 4. & Carrier pipe. \\
\hline 5. & Operation handle. \\
\hline 6. & Machine holder. \\
\hline 7. & Engine. \\
\hline
\end{tabular}

Fig (1): General view and main components of portable

\section{- Cutting blades}

In this study, four shapes of cutting blades were used with portable machine turf grass shear. Two of them were imported blades, namely: 3 teeth and 4 teeth fixed blades. While, the other two blades were modified blades, namely: 3 teeth and 4 teeth free blades constructed on disc of diameter $185 \mathrm{~mm}$. The main specification and components of these are summarized in Table (1).

\section{- Rotor head and cover protection}

The end of portable machine is the rotor head which was equipped with special setting for fixing cutter blade. The cover protection was fixed on the carrier pipe behind the cutting blade on the rotor head . 
Table (1): The main specifications and components of cutting blades.

\begin{tabular}{|c|c|c|c|c|}
\hline & \multicolumn{2}{|c|}{ imported blades } & \multicolumn{2}{|c|}{ modified blades } \\
\hline $\begin{array}{c}\text { Shapes of } \\
\text { cutting } \\
\text { blades }\end{array}$ & & 0 & & \\
\hline $\begin{array}{l}\text { blade } \\
\text { length, } \\
\mathrm{mm}\end{array}$ & 70 & 35 & 70 & 35 \\
\hline $\begin{array}{c}\text { blade } \\
\text { width, } \\
\mathrm{mm}\end{array}$ & 48 & 48 & 40 & 40 \\
\hline $\begin{array}{c}\text { Working } \\
\text { width, } \\
\text { mm }\end{array}$ & 255 & 255 & 255 & 255 \\
\hline $\begin{array}{l}\text { No of } \\
\text { teeth / } \\
\text { blade }\end{array}$ & $\begin{array}{l}3 \text { blade fixed } \\
/ \text { disc }\end{array}$ & $\begin{array}{c}4 \text { blade } \\
\text { fixed / disc }\end{array}$ & $\begin{array}{c}3 \text { blade free / } \\
\text { disc }\end{array}$ & $\begin{array}{c}4 \text { blade free / } \\
\text { disc }\end{array}$ \\
\hline
\end{tabular}

\section{- Carrier pipe and connecting rod}

The carrier was made from aluminum pipe with the length of $150 \mathrm{~cm}$ and diameter $3 \mathrm{~cm}$. One of its ends was fixed with engine power output shaft through a centrifugal clutch and the other end fixed with rotor head. However, the connecting rod was passed through the carrier pipe and used to transmit the power between engine and rotor head which rotates the cutting blade.

\section{- Operation handles and machine holder.}

The operation handles were fixed on the carrier pipe to adjust the position of portable machine for turf grass shearing. Also, the operation components of stop switch, throttle lever and starting throttle lever latch were fixed on the right hand. However, the machine holder was used to carry the machine on the worker"s shoulder during cutting operation. 


\section{- Engine.}

A small gasoline engine $1.4 \mathrm{~kW}$, two strokes, and air cooled with overall sizes ( Length $\mathrm{x}$ Width $\mathrm{x}$ Height ) $\mathrm{cm} 181 \times 33.5 \times 32$ was used as the power source for operating portable machine cutter.

\section{B - Methods}

The shearing experiments carried out to optimize some operating parameters affecting the performance of shearing machine these parameters are:

- $\quad$ Three Kinematic parameter of 180, 240 and $290 \%$.

- $\quad$ Two Knife types (imported and modified).

- $\quad$ Two Blade number ( four and three).

\section{1 - Kinematic parameter .}

The Kinematic parameter was defined as the ratio of knife peripheral velocity to machine forward speed

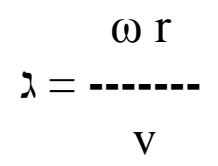

Where:

$\lambda$ : Kinematic parameter.

$\omega$ : Angular velocity of the knife, rpm

$\mathrm{r}$ : Rotor radius, $\mathrm{m}$

$\mathrm{v}$ : Machine forward speed, $\mathrm{m} / \mathrm{s}$

The proper adjustment of the kinematic parameter during turf grass shearing is great importance to decrease turf grass cutting losses and consequently increase cutting efficiency.

There were three ways in which the kinematic parameter can be varied: change the knife velocity, and machine forward speed $0.25 \mathrm{~m} / \mathrm{s}$.

All experiments were run under a constant forward speed $0.25 \mathrm{~m} / \mathrm{s}$, and different knife velocity of 44, 62 and $72 \mathrm{~m} / \mathrm{s}$, which corresponded to different kinematic parameter of 180, 240 and 290 respectively as shown in table (2):.

The performance of the turf grass shearing machine was evaluated a change in kinematic parameter, knife types of imported and modified and blades number. 
Table (2) Kinematic parameter used in portable.

\begin{tabular}{|c|c|c|c|}
\hline Knife types & $\begin{array}{l}\text { Blade } \\
\text { number }\end{array}$ & $\begin{array}{c}\text { Knife velocity } \\
\mathrm{m} / \mathrm{s}\end{array}$ & $\begin{array}{c}\text { Kinematic parameter } \\
\%\end{array}$ \\
\hline \multirow{6}{*}{ imported } & \multirow[t]{3}{*}{3} & 44 & 180 \\
\hline & & 62 & 240 \\
\hline & & 72 & 290 \\
\hline & \multirow[t]{3}{*}{4} & 44 & 180 \\
\hline & & 62 & 240 \\
\hline & & 72 & 290 \\
\hline \multirow{6}{*}{ modified } & \multirow[t]{3}{*}{3} & 44 & 180 \\
\hline & & 62 & 240 \\
\hline & & 72 & 290 \\
\hline & \multirow[t]{3}{*}{4} & 44 & 180 \\
\hline & & 62 & 240 \\
\hline & & 72 & 290 \\
\hline
\end{tabular}

\section{C-Measurements:}

Evaluation of the turf grass shearing machine performance was carried out by taking into consideration the following indicators.

\section{1 - Field efficiency for the portable:}

The field efficiency was calculated by using the following equation;

$$
\mathrm{E}_{\mathrm{f}}=\stackrel{\mathrm{C}_{\mathrm{ef}}}{\mathrm{C}_{\mathrm{th}}}
$$

Where:

$E_{f}$ : The field efficiency.

$\mathrm{C}_{\mathrm{ef}}$; effective field capacity in $\mathrm{m} 2 / \mathrm{h}$.

$\mathrm{C}_{\text {th }}$ : theoretical e field capacity in $\mathrm{m} 2 / \mathrm{h}$.

$$
\mathrm{C}_{\text {th }}=\mathrm{S} . \mathrm{W} / 4200
$$

Where:

$$
\begin{aligned}
& \mathrm{S}=\text { travel speed }, \text { in } \mathrm{m} / \mathrm{h} . \\
& \mathrm{W}=\text { operating width of the mower in } \mathrm{m} .
\end{aligned}
$$

The effective field capacity $\left(\mathrm{C}_{\mathrm{ef}}\right)$ is the actual average working rate of area concerning the amount of time lost during the operation.

\section{2 - Shearing efficiency:}

Shearing efficiency was calculated by using the following formula. 


$$
\mathrm{E}_{\mathrm{c}}=\frac{\mathrm{A}-\mathrm{B}}{\mathrm{A}}
$$

Where

A : height of turf grass stalks above the soil service before cutting, in $\mathrm{cm}$.

B : height of turf grass stalks above the soil after cutting, $\mathrm{cm}$.

\section{3 - Power requirements:}

The power can be calculated by measuring fuel consumption and by using the following equation.

$$
\mathrm{E}_{\mathrm{p}}=\left\{\mathrm{F}_{\mathrm{c}}\right\} \times \operatorname{LCV} \times 427 \boldsymbol{\eta}_{\mathrm{th}} \times \boldsymbol{\eta}_{\mathrm{m}}
$$

Where:

$\mathrm{F}_{\mathrm{c}}$ : The fuel consumption, $\mathrm{Kg} / \mathrm{h}$

LCV: The lower calorific value of fuel $(\mathrm{kJ} / \mathrm{kg})$, average LCV of gasoline is $11000 \mathrm{kcal} / \mathrm{kg}$.

$\boldsymbol{\eta}_{\mathrm{m}}$ : mechanical efficiency of the about $80 \%$ for gasoline engine

$\eta_{\mathrm{th}}$ : The thermal efficiency of the engine, (consider to be about 25 $\%$ for gasoline engine)

100: Thermal-mechanical equivalent, $\mathrm{kg} . \mathrm{m} / \mathrm{kJ}$.

Hence, the specific energy consumed can be calculated as follows:

$$
\mathrm{C}_{\mathrm{E}}=\left(\mathrm{E}_{\mathrm{p}} / \mathrm{C}_{\mathrm{ef}}\right), \mathrm{kW} . \mathrm{h} / \mathrm{m} 2
$$

Where:

$\mathrm{E}_{\mathrm{p}}$ : power requirement, $\mathrm{kW}$.

$\mathrm{C}_{\text {ef }}$; effective field capacity in $\mathrm{m} 2 / \mathrm{h}$

\section{4 - Operation cost:}

The operation costs of the mower were calculated according to (Awady 1978).

Where:

$$
\mathrm{C}=\mathrm{p} / \mathrm{h}(1 / \mathrm{e}+\mathrm{i} / 2+\mathrm{t}+\mathrm{r})+(1.2 \mathrm{~kW} . \mathrm{F} \mathrm{S})+\mathrm{W} / 144--(6)
$$

$\mathrm{C}:$ is the hourly cost, $\mathrm{LE} / \mathrm{h}$

$\mathrm{p}:$ is the capital investment. $(750 \mathrm{~L} . \mathrm{E})$

$\mathrm{h}:$ is the yearly operating hours, $(1000 \mathrm{~h} /$ year $)$

$\mathrm{e}:$ is life expectancy of equipment in year ( 10 year)..

$1:$ is the interest rate, $(10 \%)$

$\mathrm{t}:$ is the taxes and overheads $(2 \%)$.

$\mathrm{r}:$ is the repairs ratio of the total investment. $(10 \%)$

1.2: is a factor including reasonable estimation of the oil consumption in addition to fuel. 
$\mathrm{F}$ : is the specific fuel consumption, ( $0.9 \mathrm{~L} / \mathrm{kW} . \mathrm{h})$.

$\mathrm{S}:$ is the price of fuel per liter ( $2.35 \mathrm{~L} . \mathrm{E})$.

$\mathrm{w}:$ is the labor wage rate per month ( 500 L.E).

144 : is the reasonable estimation of monthly working hours

\section{RESULTS AND DISCUSSION}

The influences of some operating parameters on the performance of turf grass shear machine are discussed as follows:

\section{Effect of kinematic parameter on field efficiency:}

Representative values of field efficiency versus portable machine kinemetic parameters with knife types( imported and modified ) and blade number ( three and four blade) are given in Fig. 2.

Results show that, field efficiency values were increased as the kinemetic parameters increased. Data obtained show that increased the portable machine kinemetic parameters from 180 to 290, increased the field efficiency by 81.2 to $98.6 \%$ with modified knife with blades three. Decreased at the lower values of kinemetic parameters, the field efficiency was 72.2 at 180 kinemetic parameters and 86.5 at the 290 kinemetic parameters for the imported knife with blades four.

The major reason for the increase in field efficiency by increasing the kinemetic parameters is due to the less theoretical time consumed in comparison with the other items of time losses.

\section{Influence of some operating parameters on cutting efficiency:}

Cutting efficiency is greatly affected by many operating parameters. Unadjustment of these parameters caused a serious turf grass damage that tends to increase losses, and in turn decreased turf grass quality, (Fig.3).

Representative values of cutting efficiency versus portable machine kinemetic parameters with knife types( imported and modified ) and blade number ( three and four blade) are given in Fig.3.

Results show that cutting efficiency values were increased as the kinemetic parameters increased. Data obtained show that increased the portable machine kinemetic parameters from 180 to 290 , increased the cutting efficiency by 93.3 and $98.5 \%$ with modified knife with blades three. Decreased at the lower values of kinemetic parameters.

The cutting efficiency was 85.3 at 180 kinemetic parameters and 90.2 at the 290 kinemetic parameters for the imported knife with blades four. 
The major reason for the increase in cutting efficiency by increasing the kinemetic parameters.

The increase of cutting height with the decrease of kinematic parameter is due to bending of turf grass under the cutter disk of the portable machine, added to that, a great number of plants were left without cutting, resulting in a remarkable drop in cutting efficiency.

\section{Effect of kinematic parameter on specific energy consumption:}

Specific energy consumption as related to the kinemetic parameters with knife types( imported and modified) and blade number ( three and four blade).

Fig. 4 shows that the specific energy consumption decreased as the kinemetic parameters increased. Increased the portable machine kinemetic parameters from 180 to 290 in creased the fuel consumption by 20.6 and $17.7 \mathrm{~kW}$. h / fed with modified knife with blades three.. Decreased at the lower values of kinemetic parameters. The specific energy consumption was $25.7 \mathrm{~kW}$. h/ fed at 180 kinemetic parameters and $22.9 \mathrm{~kW} . \mathrm{h} / \mathrm{fed}$ at the 290 kinemetic parameters for the imported knife with blades four. The decrease of specific energy consumption by increasing the kinematic parameter is attributed to the increase of field capacity, results in low values of fuel per feddan.

\section{Cost of using the machine:}

The operating cost was determined 78 L.E / fed with knife modified and blade number three.

\section{CONCLUSION}

- The proper adjustment of the portable machine kinematic parameter during the shearing operation is of great importance to increase the field capacity and decrease cost requirements.

- Increasing the portable machine kinematic parameter from 180 to 290, increased the field efficiency by 81.2 to $98.6 \%$ with knife modified and blade number three, increased the cutting efficiency by 93.2 and $98.5 \%$ with knife modified and blade number three, and decreased the specific energy consumption by 20.6 and $17.7 \mathrm{~kW} . \mathrm{h} /$ fed with knife modified and blade number three .

- Rotary portable machine kinematic parameter of 290 minimized the mowing costs. 

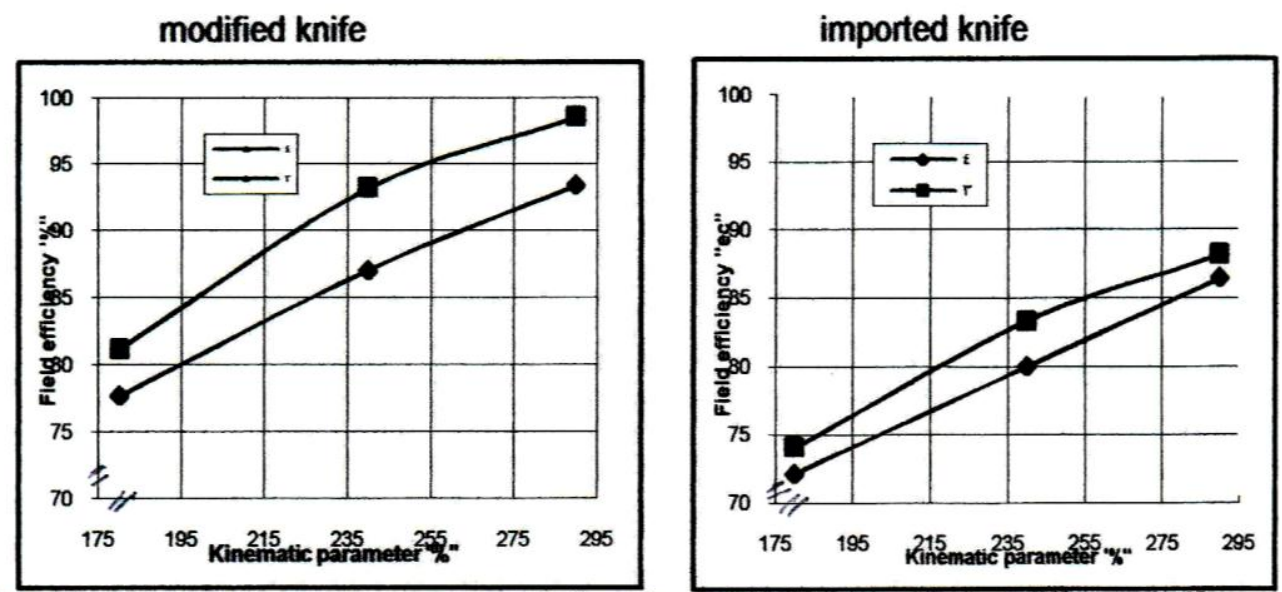

Fig (2): Effect of kinematic parameter" $y$ " on the field efficiency "Ec" at different knife types and blade number.
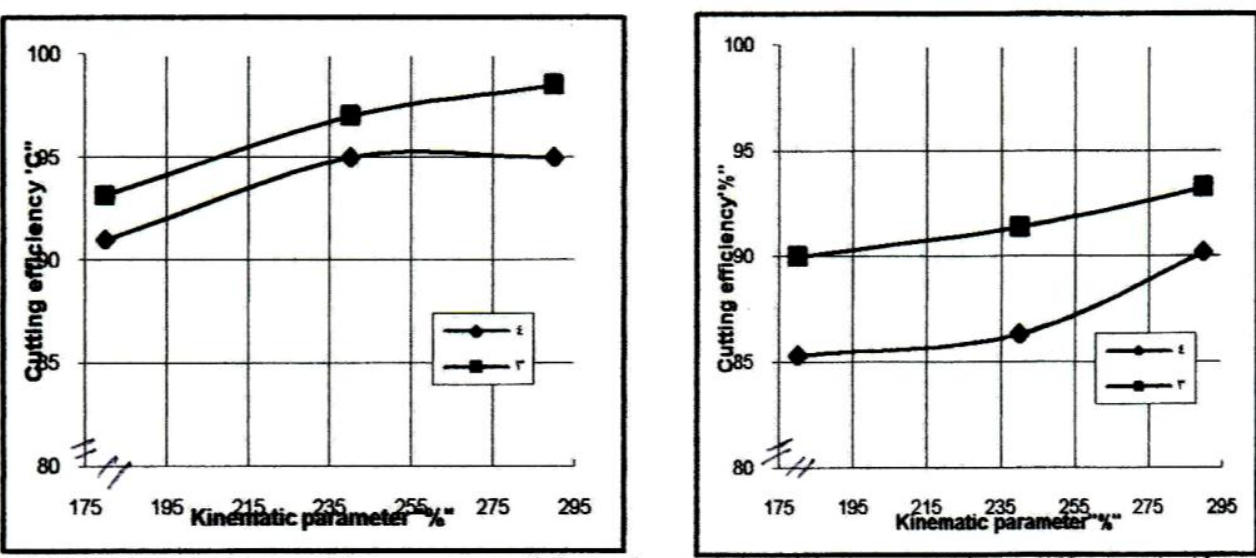

Fig (3): Effect of kinematic parameter" $y$ " on the cutting efficiency " $\mathrm{C}$ " at different knife types and blade number.
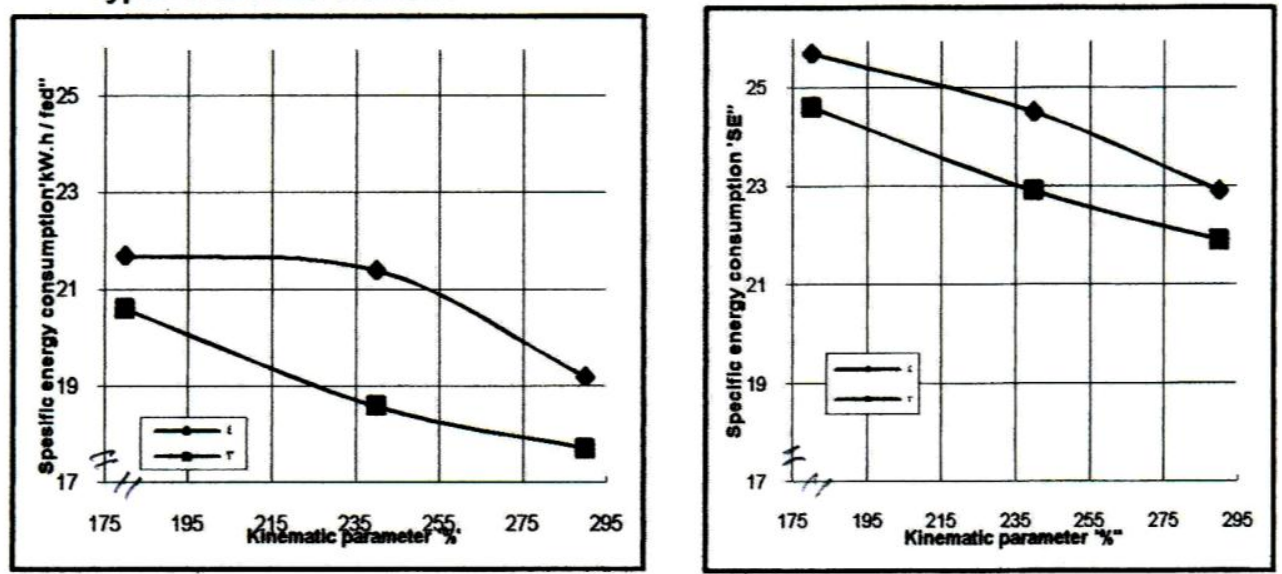

Fig. (4): Effect of kinematic "y" on the specific energy consumption "SE" at different knife types and blade number. 


\section{REFERENCES}

Awady, M.N. ( 1978 ). Tractor and farm machinery. Text book, Col.of Agric.; Ain Shams Univ.: 164 -167.

Awady, M.N.; E.Y. Ghoneim. And A.l .Hashish (1982 ). A critical comparison between wheat combine harvesters under Egyption conditions. Res. Bull. No. 1920. Ain Shams Univ.; 1-13.

EL-Danasory, M.M., (1990).Study of some design and operation parameters of reciprocating mowers for cutting stalk. Ph.D. Thesis Ag.Eng .Dept.,Fac.of Ag., Cairo Univ. Egypt

EL-Sahar, E.A., (1988). Design of harvester appropriate for Egyptian . MSe. Thesis. Fac. of Ag. Ain Shams Univ. Egypt.

Habieb, R.A. (2002). Design and performance of cutting tools of chopping machines of agricultural crop residues, $\mathrm{Ph}$. D. Thesis, Fac. of Eng., Cairo University.

Imababi, A.T. (1992). Design and development of rotary harvester for harvesting sesame crop. Ph.D.Thesis Ag. Eng.Dept., Fac. of Ag., Cairo Univ. Eygpt.

Kepner, R.A.;R. Bainer; and E.L.Barger (1982) Principle of farm machinery. $3^{\text {rd }}$ ed., Te AVI pub. Co., U.S.A: 341- 357.

Morad, M.M (1981)A study on the energy requirements for the cutting operation of different kinds of plants. Masc. Thesis, Agric. Mech. Dept., Fac. of Ag ric., Zagazig Univ.

Morad, M. M ( 1995) Optimizing the rotary mower kinematic parameter for minimum mowing cost. Misr J. Ag. Eng., 12(2): 353-363.

Prosod, J. and C.P Gupta (1973). Mechanical properties of maize stalk as related to harvesting. J.Agric.Eng., Res., 20:79-87

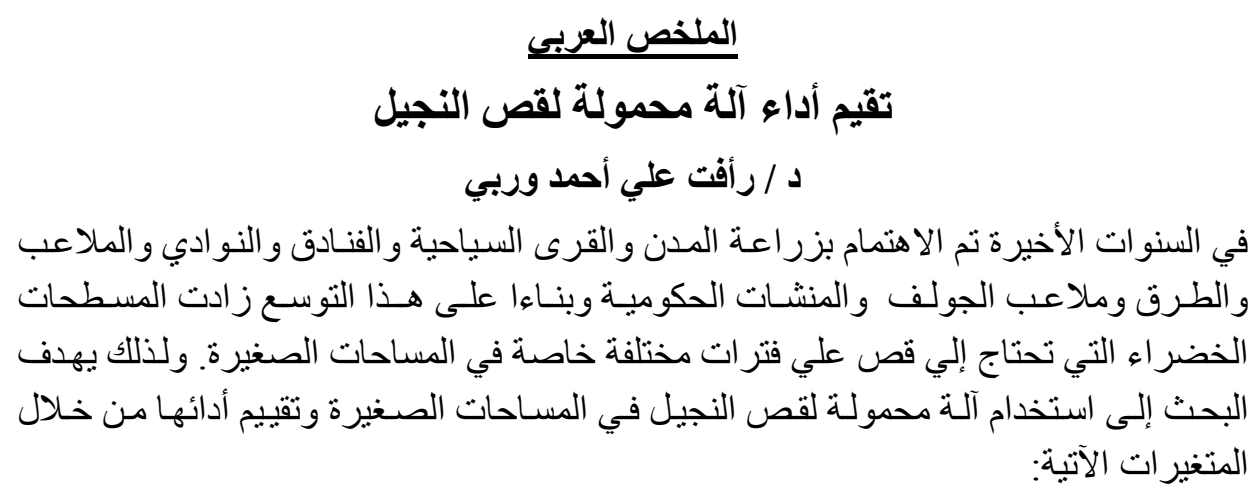

*أستاذ المساعد ـ قسم هندة الآلات والقوي الزراعية ـ كلية الهندة الزراعية ـ جامعة الأزهر - القاهرة* 
علاقـة السـر عة الدور انيـة للسـكاكين إلـى السـر عة الأماميـة للآلــة ( المعامـل الكينمـاتيكى ـ - د)

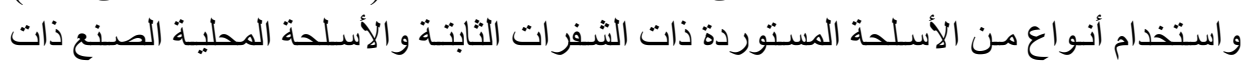

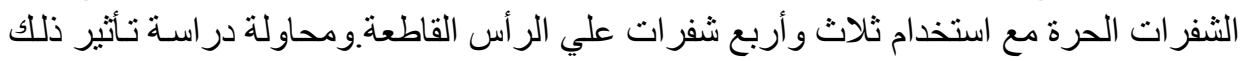
على أداء الآلة. وقد تم تقيم أداء الآلة من حيث:

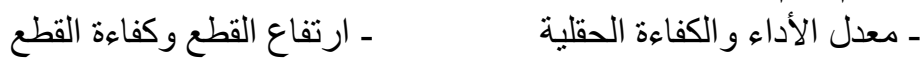

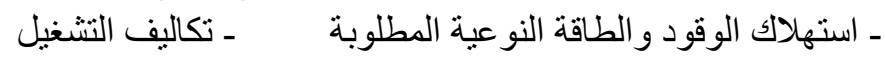
وتم القص عند نسبة رطوبة للنجيل ·ـ \% \% وارتفاع قطع ع سم من سطح الأرض.

\section{وقد وجد من تحليل النتائج ما بلى:}

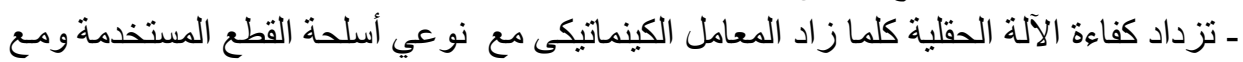

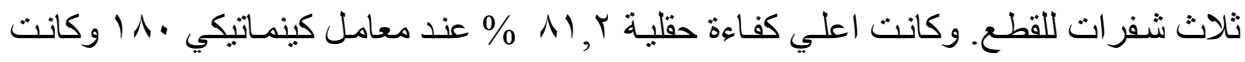

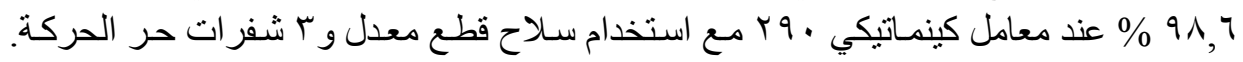

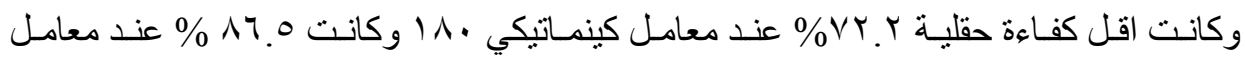

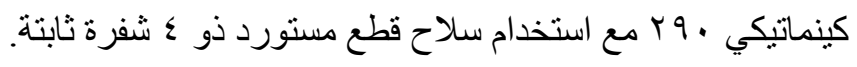

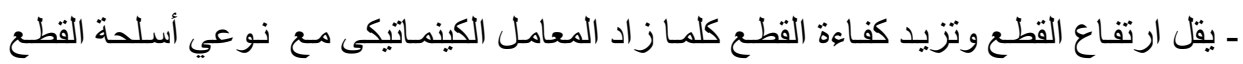

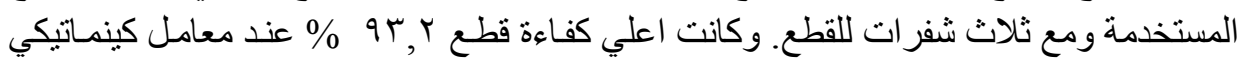

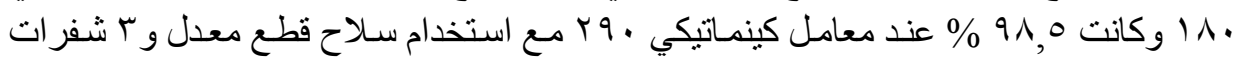

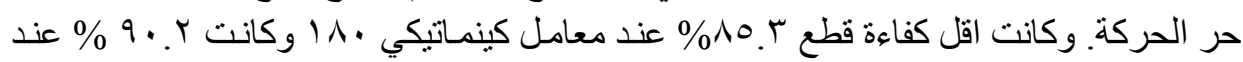

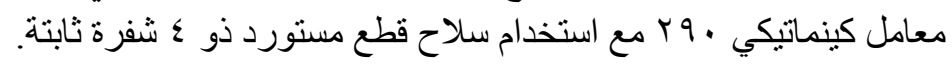

- وكانت الطاقة النو عية المطلوبة تقل مع زيادة المعامل الكينماتيكي مع أسلحة القطع المستخدمة.

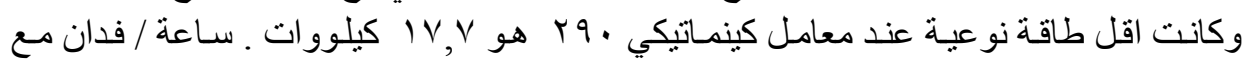

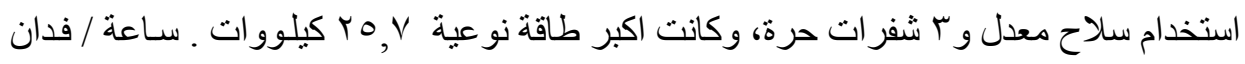

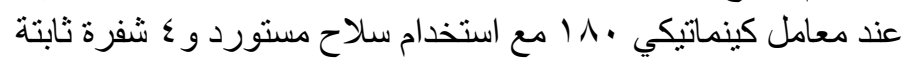

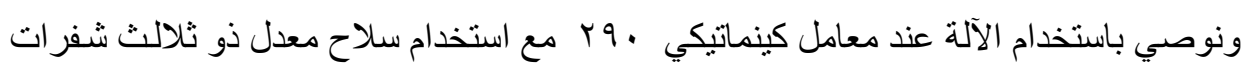

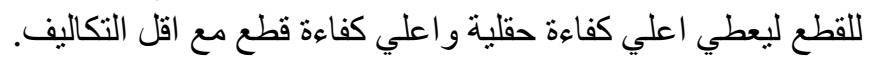

